\title{
The same adenopathy: Two diagnosis
}

\author{
Alexandra Vaz, Borges Martins, Pedro Henriques
}

\section{CASE REPORT}

We report the case of an 83 year-old woman who was hospitalized with dyspnea, dry cough, diffuse abdominal pain associated with abdominal distension, asthenia, anorexia and weight loss over the last six months. Fever, night sweats, pruritus, urinary or gastro-intestinal complaints were not present. She had a history of hypertension, obesity (BMI$32 \mathrm{Kg} / \mathrm{m}^{2}$ ), heart failure and stroke without squeal. Her physical examination showed decreased bilateral breath sounds with coarse crackles; abdominal distension with dullness to percussion; no masses or organomegaly, small-volume ascites; hard-elastic, painless, immobile adenopathies, with about $1 \mathrm{~cm}$ at the neck (right jugular chain) and $3 \mathrm{~cm}$ at the right inguinal region. Abdominal ultrasonography revealed ascites and multiple mesenteric and retroperitoneal adenopathy. A laboratory evaluation demonstrated positive $\mathrm{C}$-reactive protein $(\mathrm{RCP})(13 \mathrm{mg} / \mathrm{dl} ; \mathrm{N}<6)$, increased ESR $(83 \mathrm{~mm} ; \quad \mathrm{N}<15)$, normocytic normochromic anemia (hemoglobin 11,2 g/dl ), high levels of serum Angiotensin Converting Enzyme (ACE) $(191,6 \mathrm{UI} / \mathrm{L} ; \mathrm{N}<52)$ and elevation of CA125

Alexandra Vaz ${ }^{1}$, Borges Martins ${ }^{2}$, Pedro Henriques ${ }^{3}$ Affiliations: ${ }^{1}$ Resident of Internal Medicine, Internal Medicine Department, St. Teotónio Hospital, Viseu, Portugal; ${ }^{2}$ Graduate Assistant of Internal Medicine, Internal Medicine Department, St. Teotónio Hospital, Viseu, Portugal; ${ }^{3}$ Head of Service of Internal Medicine, Internal Medicine Department, St. Teotónio Hospital, Viseu, Portugal

Corresponding Author: Alexandra Correia Figueiredo Vaz; Quinta do Catavejo, lote 21, Mundão-Viseu, Viseu, Portugal - 3505-582; Phone - 351932665157;

Email: xana.vaz29@gmail.com

Received: 16 October 2010

Accepted: 5 November 2010

Published: 15 November 2010 tumoral marker (4052,7 UI/ml; N<35). Blood cultures, urine culture, Mantoux skin test and Mycobacterium tuberculosis research were negative. Chest and abdomino-pelvic Computed Tomography scan showed mediastinal lymphadenopathy and bilateral pulmonary fibrosis; ascites with pelvic and retroperitoneal adenopathies; suspicious appearance of the endometrium and images suggestive of peritoneal carcinomatosis. Gynecological study revealed a nodular mass compatible with left adnexal tumor and we performed an excisional biopsy of the right inguinal lymph node. Surprisingly, we found the following histopathological result: many noncaseating epithelioid granulomas (sarcomatoid type) in half of the lymph node (Figure 1, left field) and neoplastic epithelial proliferation compatible with metastatic carcinoma in other half of the lymph node (Figure 1, right field) whose immunohistochemical study suggested that it was an ovarian carcinoma (Positive estrogen, MNF 116, CK7, CAM 5.2; Negative vimentin, CK20, high molecular weight CK-34ßE12). She was targeted for palliative treatment and died

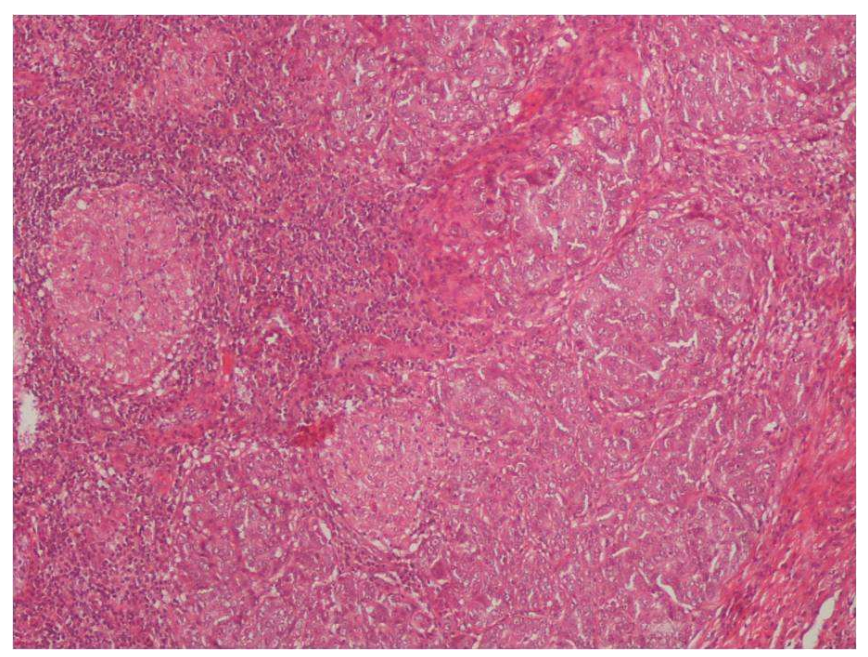

Figure 1: Left field -Granuloma; Right field- metastatic carcinoma (H\&E. 100x) 


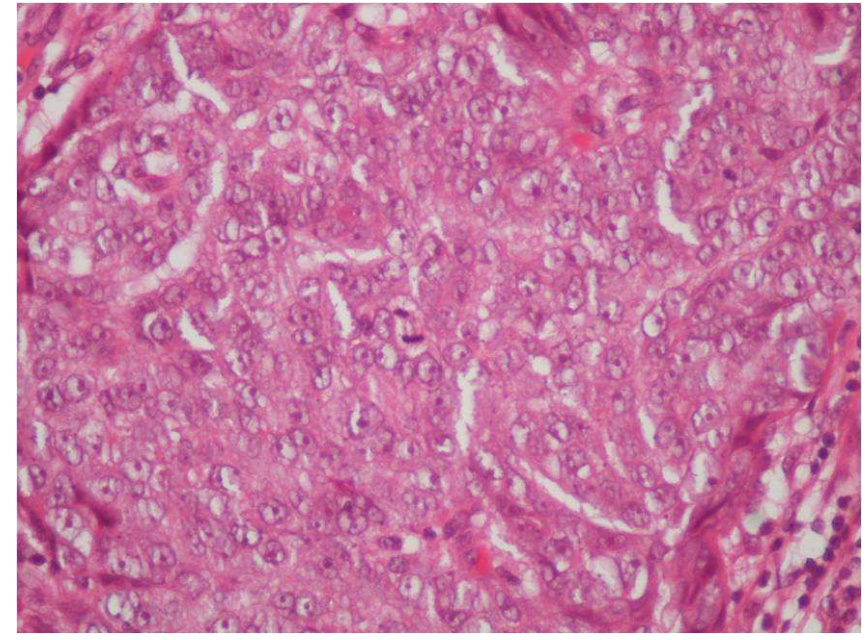

Figure 2: Expansion of the metastatic zone with mitosis in the central portion (H\&E, 400x)

after four months with a final diagnosis of 'sarcoidosis and carcinoma of the left ovary'.

\section{DISCUSSION}

This case aims to illustrate the importance of the diagnostic approach to the patient with lymphadenopathy, which requires, in most situations, a nodal biopsy [1].

\section{CONCLUSION}

In this unusual case, the adenopathies emerged as a common sign of cancer and inflammatory disease not previously known [2].

Vaz A, Martins B, Henriques P. The same adenopathy: two diagnosis. International Journal of Case Reports and Images 2010;1(3):17-18.

$* * * * * * * * *$

doi: 10.5348/ijcri-2010-11-8-CI-5

\section{Author Contributions}

Alexandra Vaz - Conception and design, Acquisition of data, Analysis and interpretation of data, Drafting the article, Critical revision of the article, Final approval of the version to be published.
Borges Martins - Conception and design, Acquisition of data, Analysis and interpretation of data, Drafting the article, Critical revision of the article, Final approval of the version to be published.

Pedro Henriques - Conception and design, Acquisition of data, Analysis and interpretation of data, Drafting the article, Critical revision of the article, Final approval of the version to be published.

\section{Guarantor}

The corresponding author is the guarantor of submission.

\section{Conflict of Interest}

Authors declare no conflict of interest.

\section{Copyright}

(C) Alexandra Vaz et. al. 2010; This article is distributed under the terms of Creative Commons attribution 3.0 License which permits unrestricted use, distribution and reproduction in any means provided the original authors and original publisher are properly credited. (Please see www.ijcasereportsandimages.com/copyrightpolicy.php for more information.)

\section{REFERENCES}

$$
\begin{aligned}
& \text { 1. www. [uptodate.com } \\
& \text { http://www.uptodate.com } \\
& \text { /patients/content/topic.do?topicKey= 6f6mjo } \\
& \text { WYWrew_4. (Accessed May, 2009). } \\
& \text { 2. www. [uptodate.com } \\
& \text { http://www.uptodate.com } \\
& \text { /patients/content/topic.do?topicKey= Q.KoM } \\
& \text { qxjvrfxZ. (Accessed May, 2009). }
\end{aligned}
$$

